\section{JURNAL EKONOMI EFEKTIF}

ISSN : $2622-8882$, E-ISSN : 2622-9935

Jurnal Ekonomi Efektif, Vol. 3, No. 1, Oktober 2020 @ Prodi Manajemen Fakultas Ekonomi Universitas Pamulang

\title{
PENGARUH DISIPLIN DAN PELATIHAN TERHADAP KINERJA KARYAWAN PADA PT. WOM DI JAKARTA
}

\author{
Dayat Hidayat \\ Universitas Pamulang \\ dosen00002@unpam.ac.id
}

\begin{abstract}
ABSTRAK
Penelitian ini bertujuan untuk mengetahui pengaruh disiplin dan pelatihan terhadap kinerja karyawan pada PT. WOM di Jakarta. Metode yang digunakan adalah explanatory research dengan teknik analisis menggunakan analisis statistik dengan pengujian regresi, korelasi, determinasi dan uji hipotesis. Hasil penelitian ini disiplin berpengaruh signifikan terhadap kinerja karyawan sebesar 51,8\%, uji hipotesis diperoleh $t$ hitung $>t$ tabel atau $(7,470$ $>2,007)$. Pelatihan berpengaruh signifikan terhadap kinerja karyawan sebesar $46,3 \%$, uji hipotesis diperoleh $t$ hitung $>\mathrm{t}$ tabel atau $(6,699>2,007)$. Disiplin dan pelatihan secara simultan berpengaruh signifikan terhadap kinerja karyawan dengan persamaan regresi $\mathrm{Y}=$ $8,769+0,387 \mathrm{X} 1+0,401 \mathrm{X} 2$ dan kontribusi pengaruh sebesar $62,4 \%$, uji hipotesis diperoleh $\mathrm{F}$ hitung > F tabel atau $(42,274>2,790)$.
\end{abstract}

Kata Kunci: Disiplin, Pelatihan, Kinerja Karyawan.

\begin{abstract}
This study aims to determine the effect of discipline and training on employee performance at PT. WOM in Jakarta. The method used is explanatory research with analysis techniques using statistical analysis with regression testing, correlation, determination and hypothesis testing. The results of this study, discipline has a significant effect on employee performance by 51.8\%, hypothesis testing is obtained $t$ count $>t$ table or (7,470> 2,007). Training has a significant effect on employee performance by $46.3 \%$, hypothesis testing is obtained $t$ count $>t$ table or (6.699> 2.007). Discipline and training simultaneously have a significant effect on employee performance with the regression equation $Y=8.769+0.387 X 1$ $+0.401 X 2$ and the influence contribution is $62.4 \%$, the hypothesis test is obtained $F$ count $>F$ table or (42.274> 2.790).
\end{abstract}

Keywords: Discipline, Training, Employee Performance. 


\section{PENDAHULUAN}

\section{A. Latar Belakang Masalah}

Dewasa ini tingkat pertumbuhan mobilitas pemakaian sepeda motor semakin meningkat seiring dengan sarana transportasi yang juga semakin membaik. Salah satu perusahaan pembiayaan yang mencover penjualan sepeda motor merek Honda adalah PT. WOM dimana perusahaan ini merupakan anak perusahaan dari PT. Astra Honda Motor. Perusahaan dibentuk sebagai jawaban manajemen atas meningkatkanya pertumbuhan pasar sepeda motor sebagai pilihan masayarakat dalam hal keinginan memeiliki alat transportasi tersebut. Dengan PT. WOM sebagai perusahaan pembiayaan pembelian sepeda motor maka konsumen akan memiliki keleluasaan dalam penghitungan dan kemampuan pembayaran yang disesuaikan dengan kondisi konsumen. Terbukti dengan sistem pembiayaan yang dijalankan mampu mendongkrak penjualan dari waktu ke waktu. Pertumbuhan pasar motor di Indonesia semakin meningkat dari tahun ketahun. Industri sepeda motor dituntut untuk dapat menyesuaikan produknya sesuai dengan kebutuhan dan keinginan konsumen. Data tersebut terlihat dari data AISI (Asosiasi Industri Sepeda Motor Indonesia).

Pertumbuhan lingkungan bisnis yang sangat cepat menuntut peran sumber daya manusia dalam keunggulan bersaing, hal ini juga berarti bahwa perusahaan harus dapat meningkatkan hasil kerja yang diraih sekarang untuk dapat memperoleh hasil kerja yang lebih baik di masa depan. Salah satu faktor yang sangat berpengaruh dalam sumber daya manusia adalah faktor kepelatihanan.

Salah satu aspek yang juga mampu mencapai keberhasilan perusahaan juga terkait disiplin kerja karyawan. Disiplin yang terkait dengan taat aturan waktu berkeja, taat pada peraturan yang dibuat oleh perusahaan, taat pada aturan norma dan perundangan lainnya serta taat pada perilaku dalam melaksanakan pekerjaan.

Menurut Hasibuan (2013), menyatakan bahwa "Kepelatihanan adalah kesadaran akan kesediaan seseorang dalam menaati semua peraturan perusahaan dan norma-norma yang berlaku". Jika lingkungan kerja semuanya pelatihan, maka seorang karyawan akan ikut pelatihan, tetapi jika lingkungan kerja perusahaan tidak pelatihan, maka seorang karyawan juga akan ikut tidak pelatihan. Untuk itu sangat sulit bagi lingkungan kerja yang tidak pelatihan tetapi ingin menerapkan kepelatihanan karyawan, karena lingkungan kerja akan menjadi panutan bagi para karyawan.

Pelatihan kerja dapat dilihat sebagai sesuatu yang besar manfaatnya, baik bagi kepentingan perusahaan maupun bagi para karyawan, bagi perusahaan adanya pelatihan kerja akan menjamin terpeliharanya tata tertib dan kelancaran pelaksanaan tugas sehingga diperoleh hasil yang optimal. Adapun bagi karyawan akan diperoleh suasana kerja yang menyenangkan sehingga akan menambah semangat kerja dalam melaksanakan pekerjaannya. Dengan demikian, karyawan dapat melaksanakan tugasnya dengan penuh kesadaran serta dapat mengembangkan tenaga dan pikirannya dengan maksimal.

Menurut Mangkunegara (2013) mengemukakan bahwa "Pelatihan (training) adalah suatu proses pendidikan jangka pendek yang mempergunakan prosedur sistematis dan terorganisasi, karyawan non manajerial mempelajari pengetahuan dan keterampilan teknis dalam tujuan yang terbatas". Semakin banyak karyawan yang diberikan kesempatan untuk mengikuti pelatihan dapat meningkatkan kinerja perusahaan.

Secara umum dapat dikatakan bahwa kinerja karyawan yang baik. Keberhasilan perusahaan dalam mengatur dan memberdayakan sumber daya manusia yang merupakan aset perusahaan dapat meningkatkan penghasilan perusahaan sehingga perusahaan dapat 
bertahan ditengah gempuran persaingan dengan perusahaan lain yang sejenis, kunci dari keberhasilan perusahaan dalam hal ini tidak terlepas dari faktor manusia sebagai variabel yang mempunyai pengaruh sangat besar dan menentukan maju tidaknya perusahaan.

Berdasarkan uraian di atas, maka penulis tertarik mengambil judul: "Pengaruh Disiplin Kerja Dan Pelatihan Terhadap Kinerja Karyawan Pada PT. WOM".

\section{B. Rumusan Masalah}

1. Adakah pengaruh antara disiplin terhadap kinerja karyawan pada PT. WOM di Jakarta ?.

2. Adakah pengaruh antara pelatihan terhadap kinerja karyawan pada PT. WOM di Jakarta?.

3. Adakah pengaruh antara disiplin dan pelatihan terhadap kinerja karyawan pada PT. WOM di Jakarta?.

\section{Tujuan Penelitian}

1. Untuk mengetahui pengaruh antara disiplin terhadap kinerja karyawan pada PT. WOM di Jakarta.

2. Untuk mengetahui pengaruh antara pelatihan terhadap kinerja karyawan pada PT. WOM di Jakarta.

3. Untuk mengetahui pengaruh secara simultan antara disiplin dan pelatihan terhadap kinerja karyawan pada PT. WOM di Jakarta.

\section{METODE PENELITIAN}

\section{Populasi}

Populasi dalam penelitian ini berjumlah 54 responden PT. WOM di Jakarta

2. Sampel

Teknik pengambilan sampling dalam penelitian ini adalah samplel jenuh, dimana semua anggota populasi dijasikan sebagai sampel. Dengan demikian sampel dalam penelitian ini berjumlah 54 responden.

\section{Jenis Penelitian}

Jenis penelitian yang dipakai adalah asosiatif, dimana tujuannya adalah untuk mengetahui pengaruh antara variabel bebas terhadap variabel terikat baik parsial maupun simultan

\section{Metode Analisis Data}

Dalam menganalisis data digunakan uji instrumen, uji asumsi klasik, regresi, koefisien determinasi dan uji hipotesis.

\section{HASIL PENELITIAN DAN PEMBAHASAN}

\section{Analisis Deskriptif}

Pada pengujian ini digunakan untuk mengetahui skor minimum dan maksimum, mean score dan standar deviasi dari masing-masing variabel. Adapun hasilnya sebagai berikut:

Tabel 1. Hasil Analisis Descriptive Statistics

\section{Descriptive Statistics}

\begin{tabular}{l|r|r|r|r|r} 
& N & Minimum & Maximum & Mean & \multicolumn{1}{c}{ Std. Deviation } \\
\hline Disiplin (X1) & 54 & 31 & 48 & 37.02 & 4.520 \\
\hline Pelatihan (X2) & 54 & 28 & 48 & 37.46 & 3.549 \\
\hline Kinerja Karyawan (Y) & 54 & 32 & 48 & 38.09 & 3.568 \\
\hline Valid N (listwise) & 54 & & & & \\
\hline
\end{tabular}

Disiplin diperoleh varians minimum sebesar 31 dan varians maximum 48 dengan 
mean score sebesar 37,02 dengan standar deviasi 4,520.

Pelatihan diperoleh varians minimum sebesar 28 dan varians maximum 48 dengan mean score sebesar 37,46 dengan standar deviasi 3,549.

Kinerja karyawan diperoleh varians minimum sebesar 32 dan varians maximum 48 dengan mean score sebesar 38,09 dengan standar deviasi 3,568.

\section{Analisis Verifikatif.}

Pada analisis ini dimaksudkan untuk mengetahui pengaruh variabel independen terhadap variabel dependen. Adapun hasil pengujian sebagai berikut:

\section{a. Analisis Regresi Linier Berganda}

Uji regresi ini dimaksudkan untuk mengetahui perubahan variabel dependen jika variabel independen mengalami perubahan. Adapun hasil pengujiannya sebagai berikut:

\begin{tabular}{|c|c|c|c|c|c|}
\hline \multirow[b]{2}{*}{ Model } & \multicolumn{2}{|c|}{$\begin{array}{l}\text { Coefficients }^{\mathbf{a}} \\
\text { Unstandardized } \\
\text { Coefficients }\end{array}$} & \multirow{2}{*}{$\begin{array}{c}\text { Standardized } \\
\text { Coefficients } \\
\text { Beta }\end{array}$} & \multirow[b]{2}{*}{$\mathrm{t}$} & \multirow[b]{2}{*}{ Sig. } \\
\hline & $\mathrm{B}$ & Std. Error & & & \\
\hline $\begin{array}{ll}1 & \text { (Constant) }\end{array}$ & 8.769 & 3.344 & & 2.622 & .011 \\
\hline Disiplin (X1) & .387 & .083 & .490 & 4.664 & .000 \\
\hline Pelatihan (X2) & .401 & .106 & .398 & 3.793 & .000 \\
\hline
\end{tabular}

a. Dependent Variable: Kinerja Karyawan (Y)

Berdasarkan hasil pengujian pada tabel di atas, diperoleh persamaan regresi $\mathrm{Y}$ $=8,769+0,387 \mathrm{X} 1+0,401 \mathrm{X} 2$. Dari persamaan tersebut dijelaskan sebagai berikut:

1) Konstanta sebesar 8,769 diartikan jika disiplin dan pelatihan tidak ada, maka telah terdapat nilai kinerja karyawan sebesar 8,769 point.

2) Koefisien regresi disiplin sebesar 0,387, angka ini positif artinya setiap ada peningkatan disiplin sebesar 0,387 maka kinerja karyawan juga akan mengalami peningkatan sebesar 0,387 point.

3) Koefisien regresi pelatihan sebesar 0,401, angka ini positif artinya setiap ada peningkatan pelatihan sebesar 0,401 maka kinerja karyawan juga akan mengalami peningkatan sebesar 0,401 point.

\section{b. Analisis Koefisien Korelasi}

Analisis koefisien korelasi dimaksudkan untuk mengetahui tingkt kekuatan hubungan dari variabel independen terhadap variabel dependen baik secara parsial maupun simultan. Adapun hasil pengujian sebagai berikut:

Tabel 3. Hasil Pengujian Koefisien Korelasi Disiplin Terhadap Kinerja Karyawan.

\section{Correlations $^{\mathrm{b}}$}

\begin{tabular}{llr|r} 
& & Disiplin $(\mathrm{X} 1)$ & Kinerja Karyawan (Y) \\
\hline Disiplin (X1) & Pearson Correlation & 1 & $.719^{* *}$ \\
\cline { 2 - 4 } & Sig. (2-tailed) & & .000 \\
\hline Kinerja Karyawan (Y) & Pearson Correlation & $.719^{* *}$ & 1 \\
\cline { 2 - 4 } & Sig. (2-tailed) & .000 & \\
\hline
\end{tabular}

Berdasarkan hasil pengujian diperoleh nilai korelasi sebesar 0,719 artinya disiplin memiliki hubungan yang kuat terhadap kinerja karyawan. 
Tabel 4. Hasil Pengujian Koefisien Korelasi Pelatihan Terhadap Kinerja Karyawan. Correlations $^{b}$

\begin{tabular}{llr|r} 
& & Pelatihan (X2) & Kinerja Karyawan (Y) \\
\hline Pelatihan $(\mathrm{X} 2)$ & Pearson Correlation & 1 & $.681^{* *}$ \\
\cline { 2 - 4 } & Sig. (2-tailed) & & .000 \\
\hline Kinerja Karyawan $(\mathrm{Y})$ & Pearson Correlation & $.681^{* *}$ & 1 \\
\cline { 2 - 4 } & Sig. (2-tailed) & .000 & \\
\hline
\end{tabular}

Berdasarkan hasil pengujian diperoleh nilai korelasi sebesar 0,681 artinya pelatihan memiliki hubungan yang kuat terhadap kinerja karyawan.

Tabel 5. Hasil Pengujian Koefisien Korelasi Disiplin dan Pelatihan Secara Simultan Terhadap Kinerja Karyawan. Model Summary

\begin{tabular}{|c|c|c|c|c|}
\hline \multicolumn{5}{|c|}{ IModel summary } \\
\hline Model & $\mathrm{R}$ & R Square & $\begin{array}{l}\text { Adjusted R } \\
\text { Square }\end{array}$ & $\begin{array}{l}\text { Std. Error of the } \\
\text { Estimate }\end{array}$ \\
\hline 1 & $.790^{\mathrm{a}}$ & .624 & .609 & 2.231 \\
\hline
\end{tabular}

a. Predictors: (Constant), Pelatihan (X2), Disiplin (X1)

Berdasarkan hasil pengujian diperoleh nilai korelasi sebesar 0,790 artinya disiplin dan pelatihan secara simultan memiliki hubungan yang kuat terhadap kinerja karyawan.

\section{c. Analisis Koefisien Determinasi}

Analisis koefisien determinasi dimaksudkan untuk mengetahui besarnya persentase pengaruh dari variabel independen terhadap variabel dependen baik secara parsial maupun simultan. Adapun hasil pengujian sebagai berikut:

Tabel 6. Hasil Pengujian Koefisien Determinasi Disiplin Terhadap Kinerja Karyawan.
Model Summary

\begin{tabular}{|c|c|c|c|c|}
\hline \multicolumn{5}{|c|}{ any } \\
\hline Model & $\mathrm{R}$ & R Square & $\begin{array}{l}\text { Adjusted R } \\
\text { Square }\end{array}$ & $\begin{array}{c}\text { Std. Error of the } \\
\text { Estimate }\end{array}$ \\
\hline 1 & $.719^{a}$ & .518 & .508 & 2.502 \\
\hline
\end{tabular}

Berdasarkan hasil pengujian diperoleh nilai determinasi sebesar 0,518 artinya disiplin memiliki kontribusi pengaruh sebesar 51,8\% terhadap kinerja karyawan.

Tabel 7. Hasil Pengujian Koefisien Determinasi Pelatihan Terhadap Kinerja Karyawan. Model Summary

\begin{tabular}{|c|c|c|c|c|}
\hline Model & $\mathrm{R}$ & R Square & $\begin{array}{l}\text { Adjusted R } \\
\text { Square }\end{array}$ & $\begin{array}{l}\text { Std. Error of the } \\
\text { Estimate }\end{array}$ \\
\hline 1 & $.681^{a}$ & .463 & .453 & 2.639 \\
\hline
\end{tabular}

Berdasarkan hasil pengujian diperoleh nilai determinasi sebesar 0,463 artinya pelatihan memiliki kontribusi pengaruh sebesar 46,3\% terhadap kinerja karyawan.

Tabel 8. Hasil Pengujian Koefisien Determinasi Disiplin dan Pelatihan Terhadap Kinerja Karyawan. Model Summary

\begin{tabular}{|c|c|c|c|c|}
\hline \multicolumn{5}{|c|}{ iviouet sumimaiy } \\
\hline Model & $\mathrm{R}$ & R Square & $\begin{array}{l}\text { Adjusted R } \\
\text { Square }\end{array}$ & $\begin{array}{l}\text { Std. Error of the } \\
\text { Estimate }\end{array}$ \\
\hline 1 & $.790^{a}$ & .624 & .609 & 2.231 \\
\hline
\end{tabular}

Berdasarkan hasil pengujian diperoleh nilai determinasi sebesar 0,624 artinya disiplin dan pelatihan secara simultan memiliki kontribusi pengaruh sebesar $62,4 \%$ terhadap kinerja karyawan, sedangkan sisanya sebesar 37,6\% dipengaruhi faktor lain. 


\section{d. Uji Hipotesis}

Uji hipotesis Parsial (Uji t)

Pengujian hipotesis dengan uji t digunakan untuk mengetahui hipotesis parsial mana yang diterima.

Hipotesis pertama: Terdapat pengaruh yang signifikan antara disiplin terhadap kinerja karyawan.

Tabel 9. Hasil Uji Hipotesis Disiplin Terhadap Kinerja Karyawan. Coefficients $^{a}$

Unstandardized

Coefficients

\begin{tabular}{|c|c|c|c|c|c|c|}
\hline \multirow{2}{*}{\multicolumn{2}{|c|}{ Model }} & \multicolumn{2}{|c|}{ Coefficients } & \multirow{2}{*}{$\begin{array}{l}\text { Coefficients } \\
\text { Beta }\end{array}$} & \multirow[b]{2}{*}{$t$} & \multirow[b]{2}{*}{ Sig. } \\
\hline & & $\mathrm{B}$ & Std. Error & & & \\
\hline 1 & (Constant) & 17.074 & 2.834 & & 6.024 & .000 \\
\hline & Disiplin (X1) & .568 & .076 & .719 & 7.470 & .000 \\
\hline
\end{tabular}

a. Dependent Variable: Kinerja Karyawan (Y)

Berdasarkan hasil pengujian pada tabel di atas, diperoleh nilai $\mathrm{t}$ hitung $>\mathrm{t}$ tabel atau $(7,470>2,007)$, dengan demikian hipotesis pertama yang diajukan bahwa terdapat pengaruh yang signifikan atara disiplin terhadap kinerja karyawan diterima.

Tabel 10. Hasil Uji Hipotesis Pelatihan Terhadap Kinerja Karyawan. Coefficients $^{\mathrm{a}}$

\begin{tabular}{|c|c|c|c|c|c|c|}
\hline \multicolumn{7}{|c|}{ Coefficients $^{a}$} \\
\hline \multirow{2}{*}{\multicolumn{2}{|c|}{ Model }} & \multicolumn{2}{|c|}{$\begin{array}{l}\text { Unstandardized } \\
\text { Coefficients }\end{array}$} & \multirow{2}{*}{$\begin{array}{l}\text { Standardized } \\
\text { Coefficients } \\
\text { Beta }\end{array}$} & \multirow[b]{2}{*}{$\mathrm{t}$} & \multirow[b]{2}{*}{ Sig. } \\
\hline & & B & Std. Error & & & \\
\hline 1 & (Constant) & 12.459 & 3.843 & & 3.242 & .002 \\
\hline & Pelatihan (X2) & .684 & .102 & .681 & 6.699 & .000 \\
\hline
\end{tabular}

Berdasarkan hasil pengujian pada tabel di atas, diperoleh nilai $t$ hitung $>t$ tabel atau $(6,699>2,007)$, dengan demikian hipotesis kedua yang diajukan bahwa terdapat pengaruh yang signifikan atara pelatihan terhadap kinerja karyawan diterima.

\section{Uji Hipotesis Simultan (Uji F)}

Pengujian hipotesis dengan uji $\mathrm{F}$ digunakan untuk mengetahui hipotesis simultan yang mana yang diterima.

Hipotesis ketiga Terdapat pengaruh yang signifikan antara disiplin dan pelatihan terhadap kinerja karyawan.

Tabel 11. Hasil Uji Hipotesis Disiplin dan Pelatihan Terhadap Kinerja

\section{Karyawan.}

ANOVA $^{a}$

\begin{tabular}{ll|r|r|r|r|r} 
Model & & Sum of Squares & df & Mean Square & \multicolumn{1}{c}{ F } & \multicolumn{1}{c}{ Sig. } \\
\hline 1 & Regression & 420.741 & 2 & 210.370 & 42.274 & $.000^{\mathrm{b}}$ \\
\cline { 2 - 7 } & Residual & 253.796 & 51 & 4.976 & & \\
\cline { 2 - 7 } & Total & 674.537 & 53 & & & \\
\hline
\end{tabular}

Berdasarkan hasil pengujian pada tabel di atas, diperoleh nilai $\mathrm{F}$ hitung $>\mathrm{F}$ tabel atau $(42,274>2,790)$, dengan demikian hipotesis ketiga yang diajukan bahwa terdapat pengaruh yang signifikan atara disiplin dan pelatihan terhadap kinerja karyawan diterima.

\section{PEMBAHASAN HASIL PENELITIAN}

\section{Pengaruh Disiplin Terhadap Kinerja Karyawan}

Disiplin berpengaruh signifikan terhadap kinerja karyawan dengan korelasi sebesar 0,719 atau memiliki hubungan yang kuat dengan kontribusi pengaruh sebesar $51,8 \%$. Pengujian hipotesis diperoleh nilai $t$ hitung $>t$ tabel atau $(7,470>2,007)$. Dengan demikian hipotesis pertama yang diajukan bahwa terdapat berpengaruh 
signifikan antara disiplin terhadap kinerja karyawan diterima.

\section{Pengaruh Pelatihan Terhadap Kinerja Karyawan}

Pelatihan berpengaruh signifikan terhadap kinerja karyawan dengan korelasi sebesar 0,681 atau memiliki hubungan yang kuat dengan kontribusi pengaruh sebesar $46,3 \%$. Pengujian hipotesis diperoleh nilai $t$ hitung $>t$ tabel atau $(6,699>2,007)$. Dengan demikian hipotesis kedua yang diajukan bahwa terdapat berpengaruh signifikan antara pelatihan terhadap kinerja karyawan diterima.

\section{Pengaruh Disiplin dan Pelatihan Terhadap Kinerja Karyawan}

Disiplin dan pelatihan berpengaruh signifikan terhadap kinerja karyawan dengan diperoleh persamaan regresi $\mathrm{Y}=8,769+0,387 \mathrm{X} 1+0,401 \mathrm{X} 2$, nilai korelasi sebesar 0,790 atau memiliki hubungan yang kuat dengan kontribusi pengaruh sebesar $62,4 \%$ sedangkan sisanya sebesar 37,6\% dipengaruhi faktor lain. Pengujian hipotesis diperoleh nilai $\mathrm{F}$ hitung $>\mathrm{F}$ tabel atau $(42,274>2,790)$. Dengan demikian hipotesis ketiga yang diajukan bahwa terdapat berpengaruh signifikan antara disiplin dan pelatihan terhadap kinerja karyawan diterima.

\section{PENUTUP}

\section{Kesimpulan}

a. Disiplin berpengaruh signifikan terhadap kinerja karyawan dengan kontribusi pengaruh sebesar 51,8\%. Uji hipotesis diperoleh nilai t hitung $>\mathrm{t}$ tabel atau $(7,470>$ 2,007).

b. Pelatihan berpengaruh signifikan terhadap kinerja karyawan dengan kontribusi pengaruh sebesar 46,3\%. Uji hipotesis diperoleh nilai t hitung > t tabel atau $(6,699>$ 2,007).

c. Disiplin dan pelatihan berpengaruh signifikan terhadap kinerja karyawan dengan kontribusi pengaruh sebesar $62,4 \%$ sedangkan sisanya sebesar $37,6 \%$ dipengaruhi faktor lain. Uji hipotesis diperoleh nilai $F$ hitung > F tabel atau $(42,274>2,790)$.

\section{Saran}

a. Perusahaan perlu melakukan pelatihan secara intensif agar karyawan memiliki cukup kemampuan yang baik dalam melaksanakan pekerjaannya.

b. Perusahaan harus menegakkan peraturan dengan baik sesuai dengan ketentuan yang berlaku guna menjamin karyawan diperlakukan dengan adil.

c. Kinerja perusahaan dapat ditingkatkan dengan memberdayakan karyawan dengan menegakkan peraturan yang baik dan pemberian disiplin kerja yang lebih inten lagi.

\section{DAFTAR PUSTAKA}

Abdullah, M (2014) Manajemen dan Evaluasi Kinerja Karyawan, Yogyakarta: Penerbit Aswaja Pressindo.

Dessler, G. (2006.) Manajemen Sumber Daya Manusia (Jilid II). Jakarta: Indeks.

George Terry R \& Rue, Leslie W. Rue (2016) Dasar-Dasar Manajemen, Jakarta Bumi Aksara.

Gerry Dessler (2016) Human Resources Management, Prenticehall, London: International Inc.

Hasibuan, Malayu S.P. (2016). Manajemen Sumber Daya Manusia. Edisi Revisi. Jakarta: PT Bumi Aksara.

Imam Ghozali (2017). “Aplikasi Analisis Multivariate Dengan Program SPSS”. Edisi 
Kelima. Semarang: Badan Penerbit Undip.

Istijanto (2014) "Riset Sumber Daya Manusia". Jakarta: PT. Gramedia Pustaka

Jasmani, J., \& Paeno, P. (2019). The Effect of Leadership and Competence on Lecturer

Performance and Its Implications on Student Learning Motivation at Pamulang

University. International Journal of Advances in Social and Economics, 1(4).

Luthans Fred (2014) Organizational Behavior, Ney York: McGraw-Hill, New York.

Kristianti, LS. D Sunarsi. (2020). Pengaruh Motivasi Dan Pengalaman Kerja Terhadap

Produktivitas Karyawan Pada PT. Mobilindo Perkasa Di Tangerang. Value: Jurnal

Manajemen dan Akuntansi 15 (2), 87-95.

Mangkunegara, Prabu Anwar. (2016). Evaluasi Kinerja SDM. Cetakan ke tujuh, PT Refika Aditama: Bandung.

Pranoto, P., Jasmani, J., \& Marayasa, I. N. (2019). Pelatihan Digital Marketing Untuk Peningkatan Perekonomian Anggota Karang Taruna Al Barkah Di Kampung Cicayur-Tangerang. Jurnal Pengabdian Dharma Laksana, 1(2), 250-258.

Prasada, D., Sunarsi, D., \& Teriyan, A. (2020). Pengaruh Etos Kerja Dan Kompensasi Terhadap Komitmen Organisasi Pada DHL Logistic Di Jakarta. JENIUS (Jurnal Ilmiah Manajemen Sumber Daya Manusia), 4(1), 51-60.

Robbins, P.S, \& Judge, A.T. (2003). Organizational Behavior. Jakarta: Salemba Empat. Sugiyono (2017), "Metode Penelitian Administrasi : dilengkapi dengan Metode $R \&$ D". Bandung: Alfabeta.

Sunarsi, D. (2018). Buku Ajar: Seminar Perencanaan Sumber Daya Manusia. Tangerang Selatan: Asmoro Mediatama

Sunarsi, D. (2018). Pengembangan Sumber Daya Manusia Strategik \& Karakterisrik Sistem Pendukungnya : Sebuah Tinjauan. Jurnal Ilmiah MEA (Manajemen, Ekonomi, \& Akuntansi), 2(3), 178 - 194

Veithzal Rivai (2015) Manajemen Sumber Daya Manusia Untuk Perusahaan, Jakarta: Raja Grafindo Persada.

Wibowo (2015) Manajemen Kinerja, Jakarta: PT. Raja Grafindo Persada

Yuangga, K. D., \& Sunarsi, D. (2018). The Influence of Procrastination and Low Time Management on Student Self Efficacy (at MA Soebono Mantofani). PINISI Discretion Review, 2(1), 85-92. 